\title{
Rheumatoid factor-like IgM in Plasmodium berghei (Apicomplexa: Haemosporida) infections of BALB/c mice
}

\author{
Reuel Robert Hook, Jr. ${ }^{1}$, Theodore J. Green ${ }^{1}$ and Melissa K. Stuart ${ }^{2}$ \\ ${ }^{1}$ Department of Veterinary Pathobiology, College of Veterinary Medicine, University of Missouri, Columbia, Missouri 65211, \\ USA; \\ ${ }^{2}$ Department of Microbiology/Immunology, Kirksville College of Osteopathic Medicine, 800 W. Jefferson Street, Kirksville, \\ Missouri 63501, USA
}

Key words: Plasmodium berghei, malaria, rheumatoid factor

\begin{abstract}
Groups of female BALB/c mice infected by intravenous injection with 50 erythrocytes containing Plasmodium berghei Vincke et Lips, 1948 were sacrificed on days 3 through 12 after infection. Rheumatoid factor-like IgM (RF-IgM) and parasite-specific IgG levels were determined by enzyme-linked immunosorbent assay in serum specimens and in culture medium removed from spleen cell cultures established at sacrifice. All four mouse IgG subisotypes were recognized by RF-IgM molecules induced by Plasmodium berghei infection, and in this regard, the parasite-induced RF-IgM response resembled that induced by lipopolysaccharide polyclonal activation. Plasmodium berghei infection resulted in a biphasic RF-IgM response, with infected animals demonstrating significantly increased levels of RF-IgM early in the infection and significantly decreased levels late in the infection, compared to uninfected control mice. The decreased levels of RF-IgM observed late in infection correlated with increasing parasitaemia levels, and were primarily due to a decrease in RF-IgM specific for mouse IgG2a. Late infection levels of RF-IgM specific for IgG1, IgG2b, and IgG3 were not significantly different from those of control animals.
\end{abstract}

Rheumatoid factor (RF) is an immunoglobulin that reacts with the Fc region of IgG (Nordstrom et al. 1998). $\mathrm{RF}$ is found in patients with rheumatic conditions, most notably rheumatoid arthritis, Sjögren's syndrome, and cryoglobulinaemia, diseases in which the prevalence rates of elevated RF can exceed 90\% (Lane and Gravel 2002). In addition, RF is elevated in the serum of patients with non-rheumatic conditions, including those with persistent infections of bacterial, viral, and parasitic etiology (Lane and Gravel 2002). In the latter group, IgM molecules with RF-like activity (RF-IgM) may play a protective role in host immunity. In vitro and in vivo studies have shown that RF-IgM can enhance agglutination of IgG-coated parasites and viruses (Risemberg et al. 1969, Clarkson and Mellow 1981, Green and Packer 1984, Stuart and Green 1990), facilitate complement fixation (Carson 1984), enhance phagocytosis (Van Snick et al. 1978), and neutralise the infectivity of viruses and intracellular parasites (Coutelier and Van Snick 1988, Stuart and Green 1990, Douvas et al. 1996).

Malaria is among the chronic diseases in which elevated serum levels of RF-IgM have been reported in humans (Houba and Allison 1966, Greenwood et al. 1971). In monkeys, secondary exposure to Plasmodium knowlesi Sinton et Mulligan, 1932 (Houba and Allison 1966) or P. cynomolgi Mayer, 1907 (Klein et al. 1971) leads to rapid induction of RF-IgM. This observation prompted Green and Packer (1984) to speculate that resistance to malaria might be enhanced by RF-IgM. To test their hypothesis, the researchers added exogenous human RF-IgM to in vitro cultures of $P$. falciparum (Welch, 1897), and found that the antiglobulin facilitated the agglutination of merozoites coated with immune human or Aotus monkey IgG. In a related study, Stuart and Green (1990) generated monoclonal IgM antibodies with RF-like activity from mice immunized with $P$. falciparum. When added to parasite cultures, the IgM antiglobulins enhanced the growth inhibitory effects of parasite-specific monoclonal IgG molecules bound to the parasite surface. In some instances, the presence of monoclonal RF-IgM correlated with an increase in the number of schizonts that failed to disperse merozoites. In other cases, parasitaemia remained low in the absence of the schizont inhibition phenomenon, suggesting that RF-IgM contributes to host cell protection not only by agglutinating merozoites, but also by increasing the density of the antibody coat surrounding the parasites, thus interfering with parasiteerythrocyte interactions.

An in vivo model is needed to determine whether RFIgM can affect the outcome of malaria in an intact host. While primate models are available (Houba and Allison 1966, Klein et al. 1971), costs associated with their use are prohibitive. In this study, we have examined the production of RF-IgM in BALB/c mice infected by Plasmodium berghei Vincke et Lips, 1948. Our results suggest that a murine model would be suitable for examining the role of RF-IgM in immunity to malaria in vivo.

Address for correspondence: M.K. Stuart, Department of Microbiology/Immunology, Kirksville College of Osteopathic Medicine, 800 W. Jefferson Street, Kirksville, Missouri 63501, USA. Phone: ++1 660626 2474; Fax: ++1 660626 2523; E-mail: MStuart@kcom.edu 


\section{MATERIALS AND METHODS}

Parasites. A strain of Plasmodium berghei obtained from the Walter Reed Army Institute of Research was maintained as frozen stocks at $-85^{\circ} \mathrm{C}$ or by in vivo passage in female BALB/c mice. For in vivo passage, blood specimens collected by cardiac puncture from infected animals were diluted 1:100 in Ventrex HL-1 cell culture medium (Ventrex Laboratories, Portland, ME), and infected erythrocytes were counted by microscopic observation on a haemocytometer. To initiate new infections, blood specimens were diluted to contain 500 infected cells $/ \mathrm{ml}$ in Ventrex HL-1 medium containing 2\% foetal calf serum. Parasites were passaged twice in vivo before they were used in experiments.

Infection of mice. Specific pathogen-free female BALB/c mice, aged 6 to 8 weeks, were used in this study. In the experimental group, 50 mice were each injected intravenously (i.v.) with $50 \mathrm{P}$. berghei-infected erythrocytes in $0.1 \mathrm{ml}$ of Ventrex HL-1 medium. Ten uninfected control mice were injected i.v. with $0.1 \mathrm{ml}$ of medium alone. Five infected mice were sacrificed on days 3 through 12 post-infection (dpi), while two control mice were sacrificed on days 3 through 7 after injection with diluent. Thin smears prepared from blood specimens collected from each animal immediately prior to sacrifice were stained with modified Wright-Giemsa stain and microscopically examined to determine parasitaemia levels. At sacrifice, blood specimens were collected from each animal by cardiac puncture for determination of serum RF-IgM and parasite-specific IgG levels as described below. After allowing the blood to clot overnight at $4^{\circ} \mathrm{C}$, the serum was collected and centrifuged at $3000 \times g$ for $10 \mathrm{~min}$ at $4^{\circ} \mathrm{C}$ to remove remaining debris. The serum was diluted $1: 2$ in $0.1 \mathrm{M}$ PBS, $\mathrm{pH} 7.4$, containing $0.02 \%$ sodium azide as a preservative, and stored at $4^{\circ} \mathrm{C}$ until assayed.

Spleen cell cultures were established from infected and control mice by teasing dissected spleen tissue into Ventrex HL1 medium. After 2 washes in the medium at $400 \times g$, an aliquot of cells was removed, diluted 1:10 in 3\% glacial acetic acid, and the number of nucleated cells determined by microscopic examination. Nucleated spleen cells were resuspended at $10^{7}$ cells/ml in Ventrex HL-1 medium containing $2 \%$ foetal calf serum, $2 \mathrm{mM}$ L-glutamine, $100 \mathrm{IU} / \mathrm{ml}$ penicillin, and $100 \mu \mathrm{g} / \mathrm{ml}$ streptomycin. Cells were cultured at $37^{\circ} \mathrm{C}$ in $15 \times 60 \mathrm{~mm}$ dishes ( $5 \mathrm{ml} /$ dish) under $5 \% \mathrm{CO}_{2}$. For in vitro stimulation of spleen cells by lipopolysaccharide, cell cultures were prepared from spleens of uninfected BALB/c mice as described above, except that culture medium contained $3 \mu \mathrm{g} / \mathrm{ml}$ of lipopolysaccharide from Salmonella enteritidis (L-4505, Sigma Chemical Co., St. Louis, MO). Medium was collected individually from cultures after $96 \mathrm{~h}$ of incubation, centrifuged at $1000 \times \mathrm{g}$ at $4^{\circ} \mathrm{C}$, and the supernatants stored at $4^{\circ} \mathrm{C}$ with $0.02 \%$ sodium azide as a preservative until assayed for RF-IgM and parasite-specific IgG.

Enzyme-linked immunosorbent assay (ELISA) for determination of parasite-specific IgG. Parasite-specific IgG levels in mouse sera and spleen cell culture supernatants were measured by an indirect ELISA (Voller and Bidwell 1986) against blood-stage parasites of $P$. berghei. Plate-coating antigen was prepared by injecting female BALB/c mice i.v. with 5000 infected erythrocytes and collecting the blood by cardiac puncture when parasitaemia levels reached $22-25 \%$. The blood was diluted 1:10 in sterile PBS containing 5 units of preservative-free heparin $/ \mathrm{ml}$, washed 4 times by centrifugation for $10 \mathrm{~min}$ at $2000 \times \mathrm{g}$ at $4^{\circ} \mathrm{C}$, and resuspended at 1:10 in sterile PBS. Leucocytes were removed from the suspension by passage through a $1 \times 10 \mathrm{~cm}$ column of packed cellulose fiber (Sigma) previously equilibrated with sterile PBS. After centrifugation at $2000 \times g$ for $10 \mathrm{~min}$ at $4^{\circ} \mathrm{C}$, the erythrocytes were lysed by resuspending the cells $1: 10$ in $0.83 \%$ ammonium chloride and incubating them for $15 \mathrm{~min}$ in a $37^{\circ} \mathrm{C}$ water bath. Parasites were washed with sterile PBS by centrifugation at $2000 \times g$ for 10 $\min$ at $4^{\circ} \mathrm{C}$ until the wash fluid was clear. The parasites were resuspended in $3 \mathrm{ml}$ of sterile PBS, overlaid onto $5 \mathrm{ml}$ of Histopaque-1077 (Sigma), and centrifuged at $400 \times g$ for $30 \mathrm{~min}$ at room temperature. The band of parasites at the HistopaquePBS interface was collected, washed 3 times with PBS by centrifugation at $2000 \times \mathrm{g}$ for $10 \mathrm{~min}$ at $4^{\circ} \mathrm{C}$, and resuspended in $2 \mathrm{ml}$ of sterile PBS. Parasites were lysed by sonication and stored at $-85^{\circ} \mathrm{C}$ until used as antigen in the ELISA. Protein determinations were performed by the BCA method (Pierce Chemical Co., Rockford, IL) using bovine serum albumin as standards.

ELISA plates (Falcon ProBind, Fisher Scientific, St. Louis, MO) were sensitized by overnight incubation at $4{ }^{\circ} \mathrm{C}$ with parasite antigen diluted to $100 \mathrm{ng} / 100 \mu \mathrm{l} /$ well in $0.1 \mathrm{M}$ carbonate buffer, $\mathrm{pH}$ 9.5. The plates were blocked for $1 \mathrm{~h}$ at room temperature in PBS containing $0.02 \%$ Tween 20 and $0.25 \%$ nonfat dry milk (blocking buffer). Serum specimens from infected mice or mice injected with diluent alone were diluted $1: 10$ in blocking buffer and incubated at $100 \mu 1 /$ well overnight at $4^{\circ} \mathrm{C}$. As a negative control, serum from uninjected, naive female BALB/c mice was prepared in like manner and applied to the ELISA plates. Following incubation, the plates were washed 3 times with PBS containing 0.2\% Tween 20 (wash buffer), and then incubated for $3 \mathrm{~h}$ at room temperature with 100 $\mu 1 /$ well of affinity-purified, horseradish peroxidase-labeled, Fcspecific goat anti-mouse IgG secondary antibody (Jackson ImmunoResearch Laboratories, West Grove, PA) diluted $1: 10,000$ in blocking buffer. After 4 washes with wash buffer, $100 \mu 1 /$ well of 2,2'-azinobis [3-ethylbenzothiazoline-6-sulfonic acid] (ABTS) (Sigma) were added, and the plates were incubated for $15 \mathrm{~min}$ at room temperature. Optical densities (O.D.) were determined at $405 / 490 \mathrm{~nm}$ in an automated plate reader (Bio-Tek Instruments, Winooski, VT). Adjusted O.D. was calculated by subtracting the control group mean O.D. from the experimental group O.D. All assays were performed in triplicate.

Undiluted spleen cell culture supernatants were applied to parasite-coated ELISA plates and processed simultaneously with the serum specimens. Spent medium from nonsecreting SP2/OAg14 myeloma cells served as a negative control in the determination of parasite-specific IgG produced by spleen cell cultures.

ELISA for the determination of RF-IgM. To measure total RF-IgM activity, ELISA plates were sensitized with a mixture of mouse IgG myeloma proteins (Sigma) comprising $2.5 \mu \mathrm{g} / \mathrm{ml}$ of each subclass (IgG1 $\kappa, \operatorname{IgG} 2 \mathrm{a} \kappa, \operatorname{IgG} 2 \mathrm{~b} \kappa$, and $\operatorname{IgG} 3 \kappa)$ in carbonate buffer. Additional wells were sensitized with a single IgG subclass $(2.5 \mu \mathrm{g} / \mathrm{ml}$ in $100 \mu \mathrm{l} /$ well $)$ to determine the subisotypic specificity of RF-IgM. The antigens were allowed to coat the plates overnight at $4^{\circ} \mathrm{C}$, after which the plates were blocked as previously described. Serum specimens from injected 

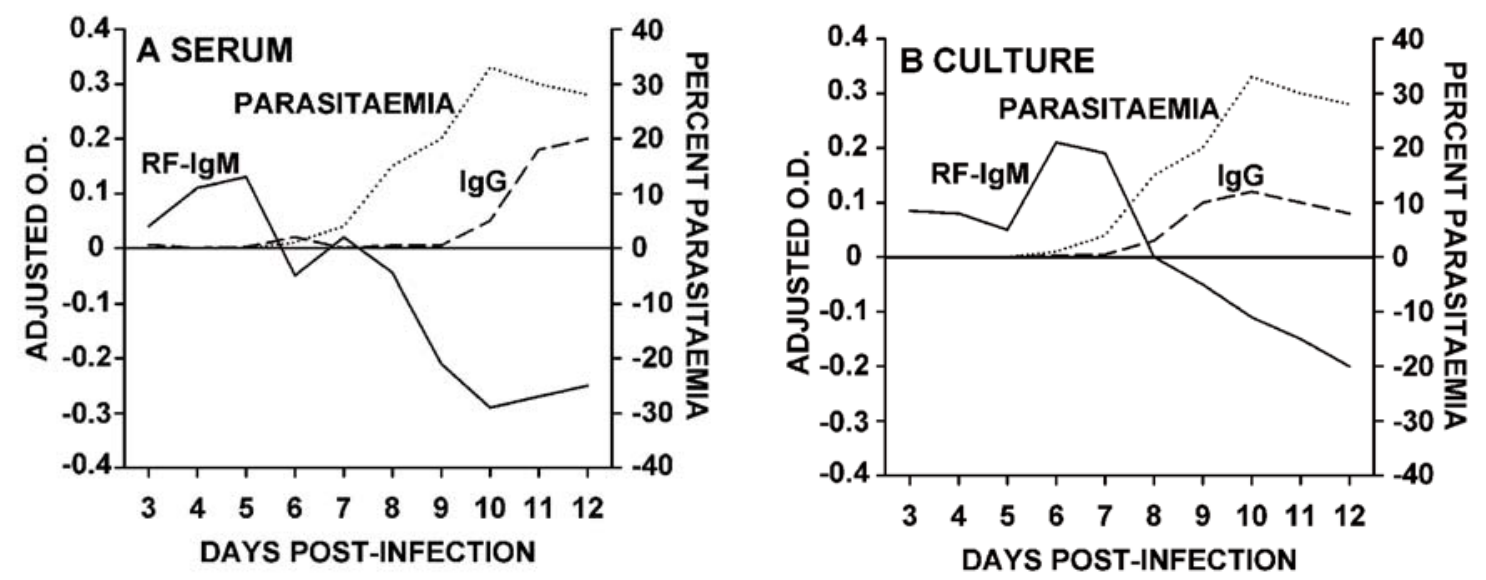

Fig. 1. Relationship among levels of RF-IgM, parasite-specific IgG, and parasitaemia at 3 through 12 days post-infection (dpi). A - Levels in serum. B - Levels in spleen cell culture supernatants. Adjusted O.D. = mean experimental O.D. - mean uninfected control O.D.

mice, diluted 1:10 in blocking buffer, were applied at 100 $\mu 1 /$ well. Pooled sera collected from retired female BALB/c breeder mice, diluted 1:50 in blocking buffer, were used as a positive control for RF-IgM, while spent medium from SP2/OAg14 cells served as a negative control. After overnight incubation at $4^{\circ} \mathrm{C}$, the plates were washed 3 times in wash buffer, and then incubated for $3 \mathrm{~h}$ at room temperature with 100 $\mu 1 /$ well of affinity purified, peroxidase-labeled, heavy chainspecific goat anti-mouse IgM secondary antibody (Jackson ImmunoResearch Laboratories). After 4 washes in wash buffer, ABTS was added and the O.D. values determined as described above. Adjusted O.D. was calculated by subtracting the control group mean O.D. from the experimental group mean O.D. All assays were performed in triplicate.

RF-IgM levels were determined in spleen culture supernatants by applying undiluted spent medium from splenocyte cultures to IgG-coated ELISA plates. The remaining steps in the ELISA were performed as described above for the serum samples.

Statistical analysis. Student's $t$-test was used to detect differences between control and experimental group responses. Correlation analysis was used to examine the relationships among parasitaemia, RF-IgM responses, and parasite-specific $\mathrm{IgG}$ responses.

\section{RESULTS}

Levels of RF-IgM in sera and spleen cell culture supernatants prepared from $P$. berghei-infected mice at 3 12 dpi are represented by the solid lines in Figs. 1A and $1 \mathrm{~B}$, respectively. The mean adjusted serum and culture RF-IgM responses were similar and demonstrated correlation $(\mathrm{r}=0.799, \mathrm{P}<0.006)$. Both serum and culture RF-IgM levels showed increases from mean control levels early in the infection; serum levels significantly increased at 4 and 5 dpi $(\mathrm{P}<0.05)$, and culture levels significantly increased at 3-7 dpi $(\mathrm{P}<0.05)$. Although decreases observed in serum RF-IgM levels were more dramatic, both serum and culture mean RF-IgM levels showed significant decreases from those of the uninfected control means $(\mathrm{P}<0.05)$. Decreases reached statistical significance at 8-12 dpi for serum, and at 10-12 dpi for spleen cell culture supernatants.

The relationships among mean percent parasitaemia, RF-IgM, and parasite-specific IgG levels in serum are presented in Fig. 1A. Parasitaemia was first detected on 6 dpi, increased to $33.3 \%$ by $10 \mathrm{dpi}$, and decreased slightly to $27.3 \%$ by $12 \mathrm{dpi}$. Parasite-specific IgG, which first showed a significant increase above control serum levels on 10 dpi $(\mathrm{P}<0.05)$, remained significantly elevated at 11 and 12 dpi $(\mathrm{P}<0.001)$. The decrease in serum RF-IgM levels was significant at $6-12 \mathrm{dpi}(\mathrm{P}<0.05)$ and correlated with increasing parasitaemia levels over the same time period $(\mathrm{r}=-0.94, \mathrm{P}<0.001)$, but did not correlate with increasing parasite-specific serum IgG levels $(r=$ $-0.655, \mathrm{P}>0.1)$. The relationships among mean percent parasitaemia, RF-IgM, and parasite-specific IgG levels in spleen cell culture supernatants are presented in Fig. 1B. The decrease in mean culture RF-IgM at 6-12 dpi correlated with both increasing parasitaemia $(\mathrm{r}=-0.945$, $\mathrm{P}<0.01)$ and with increasing parasite-specific $\operatorname{IgG}(\mathrm{r}=$ $-0.842, \mathrm{P}<0.02$ ).

Fig. 2 shows the subisotypic specificity of RF-IgM from lipopolysaccharide-stimulated control spleen cell cultures and from $P$. berghei-infected spleen cell cultures at 5 dpi. Levels of RF-IgM specific for IgG1, IgG2a, $\mathrm{IgG} 2 \mathrm{~b}$, and $\mathrm{IgG} 3$ were not significantly different from one another in either the parasite-infected or lipopolysaccharide-stimulated culture supernatants.

Fig. 3A shows the specificity of spleen cell culture RFIgM for mouse IgG1 and IgG3 at 3-12 dpi. RF-IgM specific for $\mathrm{IgG} 1$ increased to a statistically significant degree at $4-7$ dpi $(\mathrm{P}<0.05)$, while RF-IgM specific for IgG3 significantly increased at 5-10 dpi $(\mathrm{P}<0.05)$. In 


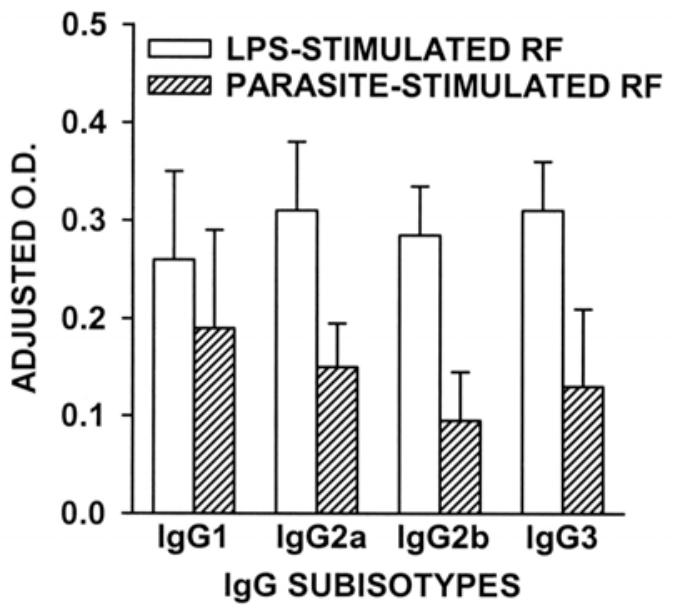

Fig. 2. Mouse IgG subclass reactivities displayed by RF-IgM from supernatants of spleen cell cultures established at $5 \mathrm{dpi}$ (parasite-stimulated) and from lipopolysaccharide-stimulated (LPS-stimulated) spleen cell cultures established from uninfected control mice. Bars indicate standard deviation from the mean. Adjusted O.D. = mean experimental O.D. - mean uninfected control O.D.

contrast to the decrease observed for total culture RF-IgM late in infection, RF-IgM specific for $\operatorname{IgG1}$ or $\operatorname{IgG} 3$ demonstrated no statistically significant decreases from corresponding control values during the infection. Although RF-IgM specific for IgG2a did not increase significantly compared to controls $(\mathrm{P}>0.05)$ during infection (Fig. 3B), anti-IgG2a RF-IgM decreased significantly on $8-12$ dpi $(\mathrm{P}<0.05)$ and reflected the decrease in total RF-IgM levels observed in spleen cell culture supernatants prepared from infected mice. RF-IgM specific for IgG2b showed significant increases at 3-7 dpi when compared to the controls $(\mathrm{P}<0.05)$ (Fig. 3B). Although a general tendency towards decreased levels was observed for RF-IgM directed against IgG2b on days 8-12 dpi, significant decreases were not seen until 11 and 12 dpi $(\mathrm{P}<0.05)$.

The results obtained in assays of serum RF-IgM for subisotypic specificity (Fig. 4) were similar to those observed for spleen cell cultures (Fig. 3). In infected mice, serum levels of RF-IgM specific for IgG1 and IgG3 were not statistically significant different from controls (Fig. $4 \mathrm{~A}$ ), while levels of serum RF-IgM reactive with $\operatorname{IgG} 2 \mathrm{a}$ and IgG2b significantly decreased at $8-12$ dpi $(\mathrm{P}<0.05)$ (Fig. 4B).

In Fig. 5, IgG subclass responses to parasite antigens detected at 8,10 , and 12 dpi in spleen cell culture supernatants are shown. The order of reactivity was $\operatorname{IgG3}>$ IgG2a $>\operatorname{IgG} 1>\operatorname{IgG} 2 \mathrm{~b}(\mathrm{P}<0.05)$. Parasite-specific IgG subclass reactivities detected in the sera of infected mice were similar to levels detected in spleen cell culture supernatants (data not shown).

\section{DISCUSSION}

Our results showed that RF-IgM levels peaked relatively early during Plasmodium berghei infections in the mouse, and declined later in the infection as parasitaemia continued to rise. These results contrast with those of other researchers, who showed that in monkeys infected with P. knowlesi (Houba and Allison 1966) or P. cynomolgi (Klein et al. 1971), increasing parasitaemia correlated with increasing levels of RF-IgM in the serum. Although malarial infections have been reported to exert a general immunosuppressive effect on the host (Greenwood et al. 1971), we do not believe this accounts for the late-onset decrease in RF-IgM levels we observed in the mouse model, since parasite-specific IgG levels continued to increase along with increasing parasitaemia. An alternative explanation for decreasing RF-IgM could be that the antiglobulin became bound to immune complexes containing $P$. berghei and parasite-specific $\operatorname{IgG}$, and thus were removed from the fluid phase of the spleen cell culture supernatants and mouse sera prior to analysis by ELISA. In both culture supernatants and sera from infected mice, parasites and parasite-specific IgG were detected after 6 dpi. Hence, all the necessary reactants for the formation of parasite/IgG/RF-IgM complexes were available at that time.

In the mouse model, the decreased level of RF-IgM observed late in $P$. berghei infection was not due to a general reduction in RF-IgM, but instead was primarily due to a decrease in RF-IgM specific for IgG2a. In spleen cell cultures established late in the infection, levels of RFIgM specific for IgG1, IgG2b, and IgG3 were not significantly different from normal controls. Serum RF-IgM levels showed a similar pattern to culture supernatant RFIgM, except that serum RF-IgM specific for IgG2b also decreased late in the infection. The observation that low parasite-specific IgG2b levels in serum coincided with decreased levels of anti-IgG2b RF-IgM further supports the notion that the antiglobulin might be removed from the fluid phase of serum by binding to complexes of parasites and IgG. However, this explanation is inconsistent with the observation that normal or increased levels of RF-IgM specific for IgG3 occurred in the presence of high levels of parasite-specific IgG3. Further investigations may reveal that the avidities of IgG3 molecules for parasite antigens, or the avidities of RF-IgM molecules for IgG3, may be lower than those of antibodies involved in the formation of complexes comprising RF-IgM, IgG2a, and $P$. berghei. The lower avidities may allow parasitespecific IgG3 and anti-IgG3 RF-IgM molecules to remain in serum and spleen culture supernatants in an uncomplexed form amenable to detection by ELISA.

The production of RF-IgM can be stimulated in mice by a variety of factors, including immunisation with lipopolysaccharide (Izui et al. 1979, Popham and Dresser 1980, Dziarski 1982a, b), secondary immunisation 

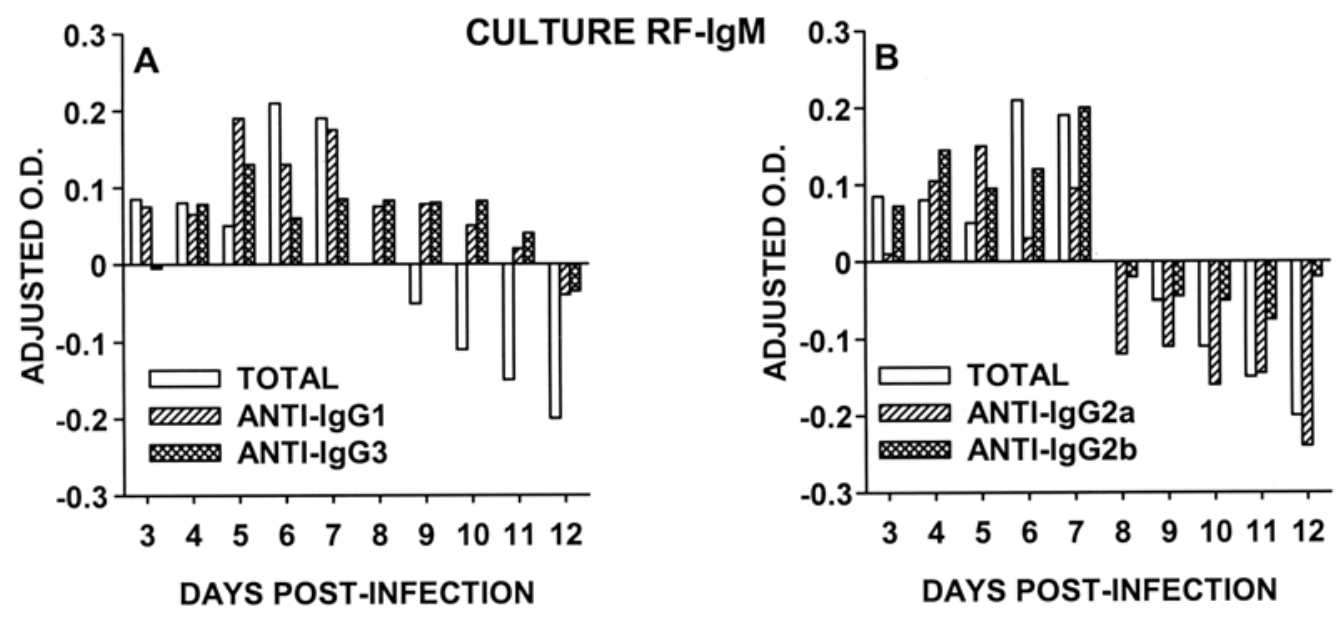

Fig. 3. Mouse IgG subclass specificity of RF-IgM from spleen cell cultures established at 3 through 12 dpi. A - RF-IgM reactive with IgG1 and IgG3. B - RF-IgM reactive with IgG2a and IgG2b. Adjusted O.D. = mean experimental O.D. - mean uninfected control O.D.
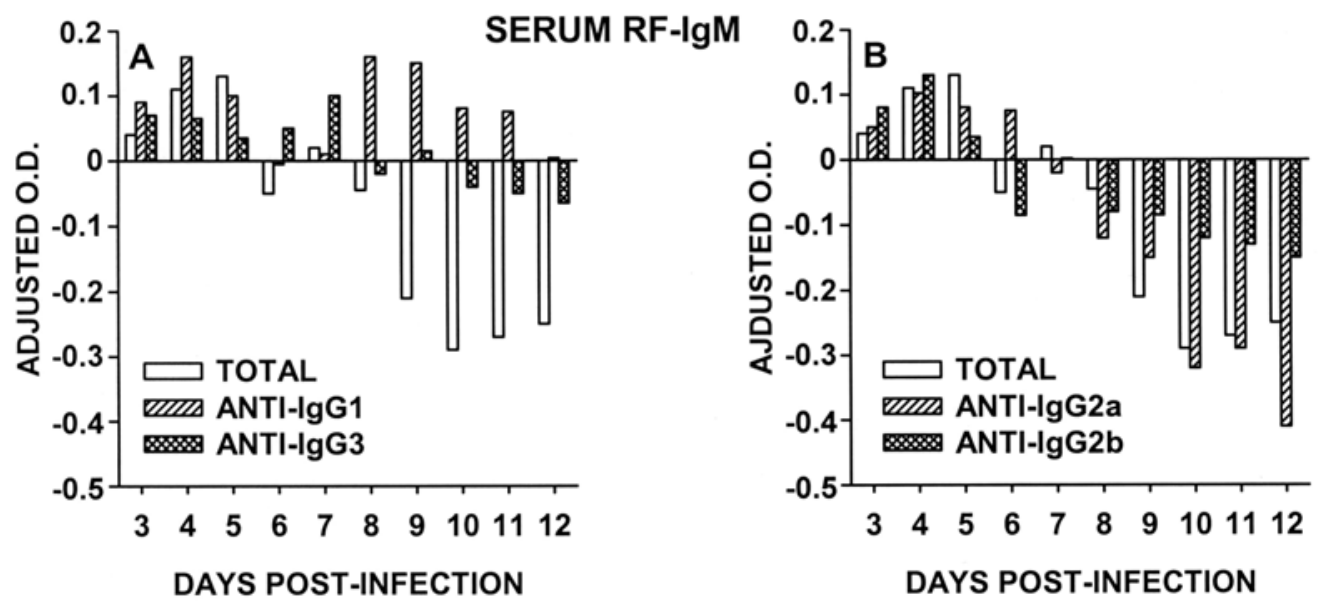

Fig. 4. Mouse IgG subclass specificity of RF-IgM from serum specimens collected from mice at 3 through 12 dpi. A - RF-IgM specific for IgG1 and IgG3. B - RF-IgM specific for IgG2a and IgG2b. Adjusted O.D. = mean experimental O.D. - mean uninfected control O.D.

with protein antigens (Nemazee and Sato 1983), and immunisation with antigen-antibody complexes (Nemazee 1985). In our study, stimulation of RF-IgM by P. berghei appeared to closely resemble the polyclonal stimulation observed with LPS immunisation in mice, since in both cases the production of RF-IgM in $P$. berghei-infected mice occurred prior to the production of parasite-specific $\mathrm{IgG}$, and thus could not be due to stimulation by specific antigen-antibody complexes. Both LPS stimulation and $P$. berghei infection resulted in the formation of RF-IgM that recognized all four murine IgG subclasses. These results contrast with those of Abdelmoula et al. (1989), who found that injection of LPS or infection of BALB/c mice by Plasmodium yoelii Landau et Killick-Kendrick, 1966 resulted in the formation of RF-IgM with nearly exclusive specificity for IgG3 in the cryoprecipitates they analysed.

In 1979, Greenwood et al. reported the presence of a malarial mitogen that could stimulate lymphocytes from both malaria-immune and malaria non-immune donors. Based on the results of our studies with $P$. berghei, the nature of this mitogen mimics LPS, which is known to stimulate the $\mathrm{CD}^{+} \mathrm{B}-1$ subset of B lymphocytes in a thymus-independent fashion (Lydyard and Grossi 2001). B-1 lymphocytes are found predominantly in the mouse peritoneal cavity and are thought to differentiate via a separate pathway than conventional B lymphocytes of the 


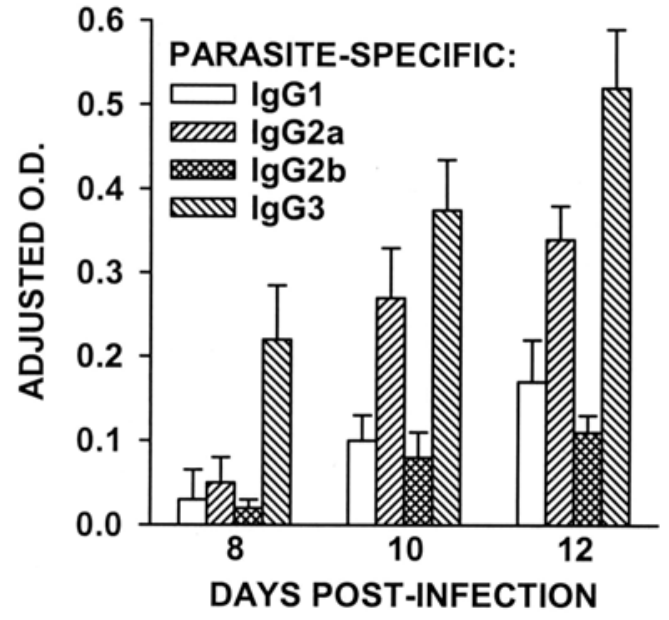

Fig. 5. Reactivity of mouse IgG subclasses with $P$. berghei blood-stage parasites. Specimens were supernatants of spleen cell cultures established from infected mice at 8, 10, and $12 \mathrm{dpi}$. Bars indicate standard deviation from the mean. Adjusted O.D. $=$ mean experimental O.D. - mean uninfected control O.D.

B-2 subset. B-1 cells express their immunoglobulins (mainly low-affinity IgM) from unmutated or minimally mutated germline genes. The so-called natural antibodies produced by B-1 cells tend to be polyreactive and represent the first line of defence against microorganisms. Typically, the antibodies also react with autoantigens, including DNA, phospholipids, cytoskeletal components, and the Fc region of IgG (Lydyard and Grossi 2001).

Evaluation of the data presented in this report indicates that $P$. berghei infections in $\mathrm{BALB} / \mathrm{c}$ mice induce a biphasic RF-IgM response and represent a suitable small animal model for examination of the relationship among malaria infection, RF-IgM induction, and parasite-specific IgG. Furthermore, the data indicate that in vitro spleen cell cultures derived from infected animals accurately reflect the RF-IgM response in vivo. It should now be possible to use this model to determine what effect passively administered RF-IgM molecules may have on the outcome of malaria in an intact animal, and to define the conditions under which RF-IgM induction in vivo may mediate a therapeutic effect. In addition, the mouse model provides a means of elucidating the fundamental differences between RF-like immunoglobulins with a protective effect from those RF molecules that induce pathology in the host. Such differences may include the tendency for different RF molecules to bind to different IgG subclasses, differ-ences in antiglobulin avidities, biases in the expression of immunoglobulin variable region gene repertoires, and the differential expression of major histocompatibility com-plex antigens in the host (Van Snick et al. 1983, Borretzen et al. 1997).

Acknowledgements. We thank Ms. Mona Garo for excellent technical assistance and Dr. L.K. Riley for review of the manuscript. This study was supported by a Committee on Research grant from the College of Veterinary Medicine, University of Missouri-Columbia.

\section{REFERENCES}

ABDELMOULA M., SPERTINI F., SHIBATA T., GYOTOKU Y., LUZUY S., LAMBERT P., IZUI S. 1989: IgG3 is the major source of cryoglobulins in mice. J. Immunol. 143: 526-532.

BORRETZEN M., CHAPMAN C., NATVIG J.B., THOMPSON K.M. 1997: Differences in mutational patterns between rheumatoid factors in health and disease are related to variable heavy chain family and germ-line gene usage. Eur. J. Immunol. 27: 735-741.

CARSON D.A. 1984: Increase in the complement-fixing ability of murine IgG anti-lymphocyte antibodies by addition of monoclonal IgM rheumatoid factors. J. Immunol. Methods 68: $103-108$.

CLARKSON A.B., MELLOW G.H. 1981: Rheumatoid factorlike IgM protects previously uninfected rat pups and dams from Trypanosoma lewisi. Science 214: 186-188.

COUTELIER J.P., VAN SNICK J. 1988: Neutralization and sensitization of lactate dehydrogenase-elevating virus with monoclonal antibodies. J. Gen. Virol. 69: 2097-2100.

DOUVAS A., TAKEHANA Y., EHRESMANN G., CHERNYOVSKIY T., DARR E.S. 1996: Neutralization of HIV type 1 infectivity by serum antibodies from a subset of autoimmune patients with mixed connective tissue disease. AIDS Res. Hum. Retroviruses 12: 1509-1517.
DZIARSKI R. 1982a: Preferential induction of autoantibody secretion in polyclonal activation by peptidoglycan and lipopolysaccharide. I. In vitro studies. J. Immunol. 128: 1018-1025.

DZIARSKI R. 1982b: Preferential induction of autoantibody secretion in polyclonal activation by peptidoglycan and lipopolysaccharide. II. In vivo studies. J. Immunol. 128: 1026-1030.

GREEN T.J., PACKER B.J. 1984: A role for rheumatoid factor enhancement of Plasmodium falciparum schizont inhibition in vitro. Infect. Immun. 46: 668-672.

GREENWOOD B.M., ODULOJU A.J., PLATTS-MILLS T.A.E. 1979: Partial characterization of a malaria mitogen. Trans. R. Soc. Trop. Med. Hyg. 73:178-182.

GREENWOOD B.M., PLAYFAIR J.H.L., TORRIGIANI G. 1971: Immunosuppression in murine malaria. I. General characteristics. Clin. Exp. Immunol. 8: 467-478.

HOUBA V., ALLISON A.C. 1966: M-antiglobulins (rheumatoid factor-like globulins) and other gammaglobulins in relation to tropical parasitic infections. Lancet 1966 (1): 848-852.

IZUI S., EISENBERG R.A., DIXON F.J. 1979: IgM rheumatoid factors in mice injected with bacterial lipopolysaccharides. J. Immunol. 122: 2096-2102. 
KLEIN F., MATTERN P., MEUWISSEN J.H.E.Th. 1971: Experimental anti-gammaG-globulins in infectious diseases. In: R. Grubb and G. Sammuelsson (Eds.), Human AntiHuman Gammaglobulins: Their Specificity and Function. Wenner-Gren Center International Symposium Series, Vol. 17. Pergamon Press, New York, pp. 63-70.

LANE S.K., GRAVEL J.W. Jr. 2002: Clinical utility of common serum rheumatologic tests. Am. Fam. Physician 65: 10731080.

LYDYARD P.M., GROSSI C.E. 2001: Cells, tissues and organs of the immune system. In: I. Roitt, J. Brostoff and D. Male (Eds.), Immunology, Sixth Edition. Mosby-Harcourt Publishers, London, pp. 15-45.

NEMAZEE D.A. 1985: Immune complexes can trigger specific, $\mathrm{T}$ cell-dependent, autoanti-IgG antibody production in mice. J. Exp. Med. 161: 242-256.

NEMAZEE D.A., SATO V.L. 1983: Induction of rheumatoid antibodies in the mouse: regulated production of autoantibody in the secondary immune response. J. Exp. Med. 158: $529-545$.

NORDSTROM E., MOLLER E., ABEDI-VALUGERDI M. 1998: Induction of IgG rheumatoid factor (RF) production by antibody-antibody (RF-like) immune complexes: the role of $\mathrm{T}$ cells, complement and $\mathrm{Fc}$ gamma receptors. J. Autoimmun. 11: 131-140.
POPHAM A.M., DRESSER D.W. 1980: Rheumatoid factors in mice: non-specific activators of heterophile rheumatoid factor production. Immunology 41: 579-585.

RISEMBERG A., DE GOMEZ A.G., RIFE U. 1969: Agglutinating factor in serum of patients with viral hepatitis. Ann. Rheum. Dis. 28: 428-430.

STUART M.K., GREEN T.J. 1990: Monoclonal IgM rheumatoid factor-like anti-globulins enhance the inhibitory effects of Plasmodium falciparum-specific monoclonal antibodies in vitro. Parasitology 101: 177-185.

VAN SNICK J.L., COULIE P.G., STEVENS M. 1983: Genetic control of rheumatoid factor production in the mouse. Role of genes linked to the immunoglobulin heavy chain locus and to the major histocompatibility complex. Arthritis Rheum. 26: 1085-1090.

VAN SNICK J.L., VAN ROOST E., MARKOWETZ B., CAMBIASO C.L., MASSON P.L. 1978: Enhancement by IgM rheumatoid factor of in vitro ingestion by macrophages and in vivo clearance of aggregated IgG or antigen-antibody complexes. Eur. J. Immunol. 8: 279-285.

VOLLER A., BIDWELL D. 1986: Enzyme-linked immunosorbent assay. In N.R. Rose, H. Friedman and J.L. Fahey (Eds.), Manual of Clinical Laboratory Immunology, Third Edition. American Society for Microbiology, Washington, D.C., pp. 99-109.

Accepted 4 February 2003 